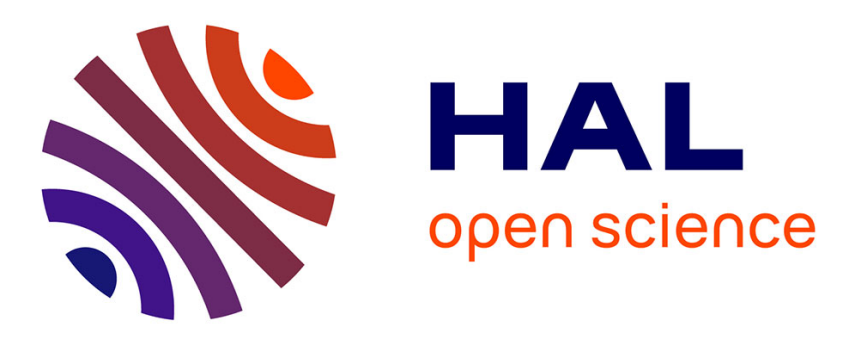

\title{
Plasmon-driven electrochemical methanol oxidation on gold nanohole electrodes
}

Liuqing Pang, Alexandre Barras, Vladyslav Mishyn, Svetlana Heyte, Egon Heuson, Hamid Oubaha, Georgiana Sandu, Sorin Melinte, Rabah

Boukherroub, Sabine Szunerits

\section{To cite this version:}

Liuqing Pang, Alexandre Barras, Vladyslav Mishyn, Svetlana Heyte, Egon Heuson, et al.. Plasmondriven electrochemical methanol oxidation on gold nanohole electrodes. ACS Applied Materials \& Interfaces, 2020, 12 (45), pp.50426-50432. 10.1021/acsami.0c14436 . hal-03089817

\section{HAL Id: hal-03089817 https://hal.science/hal-03089817}

Submitted on 6 May 2021

HAL is a multi-disciplinary open access archive for the deposit and dissemination of scientific research documents, whether they are published or not. The documents may come from teaching and research institutions in France or abroad, or from public or private research centers.
L'archive ouverte pluridisciplinaire HAL, est destinée au dépôt et à la diffusion de documents scientifiques de niveau recherche, publiés ou non, émanant des établissements d'enseignement et de recherche français ou étrangers, des laboratoires publics ou privés. 


\title{
Plasmon-Driven Electrochemical Methanol Oxidation on Gold Nanohole Electrodes
}

\author{
Liuqing Pang, ${ }^{1}$ Alexandre Barras, ${ }^{1}$ Vladyslav Mishyn, ${ }^{1}$ Svetlana Heyte, ${ }^{3}$ Egon Heuson, ${ }^{4}$ \\ Hamid Oubaha, ${ }^{2}$ Georgiana Sandu, ${ }^{2}$ Sorin Melinte, ${ }^{2}$ Rabah Boukherroub, ${ }^{1 *}$ Sabine \\ Szunerits $^{1 *}$
}

${ }^{1}$ Univ. Lille, CNRS, Centrale Lille, ISEN, Univ. Valenciennes, UMR 8520 - IEMN, F-59000 Lille, France.

${ }^{2}$ Institute of Information and Communication Technologies, Electronics and Applied Mathematics, Université catholique de Louvain, 1348 Louvain-la-Neuve, Belgium.

${ }^{3}$ Univ. Lille, CNRS, Centrale Lille, Univ. Artois, UMR 8181 - UCCS - Catalysis and Solid State Chemistry Unit, F-59000 Lille, France

${ }^{4}$ Univ. Lille, INRA, ISA, Univ. Artois, Univ. Littoral Côte d'Opale, EA 7394, ICV - Institut Charles Viollette, F-59000 Lille, France

\section{Corresponding Authors}

Rabah Boukherroub - Univ. Lille, CNRS, Centrale Lille, ISEN, Univ. Valenciennes, 8520-IEMN, F-59000 Lille, France; Email: rabah.boukherroub@univ-lille.fr

Sabine Szunerits - Univ. Lille, CNRS, Centrale Lille, ISEN, Univ. Valenciennes, 8520-IEMN, F-59000 Lille, France; Email: sabine.szunerits@univ-lille.fr 


\begin{abstract}
:
Direct methanol oxidation is expected to play a central role in low-polluting future power sources. However, the sluggish and complex electro-oxidation of methanol is one of the limiting factors for any practical application. To solve this issue, the use of plasmonic cathodes is considered a promising way to accelerate the methanol oxidation reaction. In this study we report on a novel approach for achieving enhanced methanol oxidation currents. Perforated gold thin films cathodes were decorated with $\mathrm{Pt} / \mathrm{Ru}$ via electrochemical deposition and investigated for their ability for plasmon-enhanced electrocatalytic methanol oxidation in alkaline media. The novel methanol oxidation cathode (AuNHs/PtRu), combing the strong light absorption properties of a gold nanohole array-based electrode (AuNHs) with surface anchored bimetallic $\mathrm{Pt} / \mathrm{Ru}$ nanostructures, known for their high activity towards methanol oxidation, proved to be highly efficient in converting methanol via the hot holes generated in the plasmonic electrode. Without light illumination AuNHs/PtRu displayed a maximal current density of $13.7 \mathrm{~mA} / \mathrm{cm}^{2}$ at $-0.11 \mathrm{~V} v s$. $\mathrm{Ag} / \mathrm{AgCl}$. Enhancement to $17.2 \mathrm{~mA} / \mathrm{cm}^{2}$ was achieved under $980 \mathrm{~nm}$ laser light illumination at a power density of $2 \mathrm{~W} / \mathrm{cm}^{2}$. The thermal effect was negligible in this system, underlining a dominant plasmon process. Fast generation and injection of charge carriers were also evidenced by the abrupt change in the current density upon laser irradiation. The good stability of the interface over several cycles makes this system interesting for methanol electro-oxidation.
\end{abstract}

Keywords: localized surface plasmon resonance, hot carriers, electrocatalysis, electrochemical methanol oxidation, photoelectrochemistry. 


\section{INTRODUCTION}

Direct methanol fuel cells are one of the most promising non-polluting energy sources. ${ }^{1-3}$ Despite significant advances in recent years, the development of high performing anodic catalysts for methanol oxidation remains a challenge. ${ }^{1,4-7}$ Fast surface poisoning of the Pt surface by the $\mathrm{CO}$ intermediates formed during this reaction and the high cost and scarcity of Pt-based catalyst remain hurdles to overcome. ${ }^{4,5,8}$ Methanol oxidation follows a 6-electron pathway, which is believed to occur via a dual pathway mechanism, where $\mathrm{C}-\mathrm{H}$ bond cleavage generates an adsorbed hydroxymethyl $\mathrm{CH}_{2} \mathrm{OH}$ intermediate, which is further dehydrogenated to $\mathrm{CO}_{\text {ads }}$, while $\mathrm{O}-\mathrm{H}$ bond cleavage leads to adsorbed methoxy, $\mathrm{CH}{ }_{3} \mathrm{O}$, which binds to $\mathrm{Pt}$ via the oxygen. ${ }^{4}$ The adsorbed methoxy intermediate is further dehydrogenated to $\mathrm{H}_{2} \mathrm{CO}_{\mathrm{ads}}$, which can subsequently desorb as formaldehyde. The main poisoning species for Pt, identified in many studies, is surface-bonded carbon monoxide $\left(\mathrm{CQ}_{\mathrm{ds}}\right)$. As the interaction between adsorbed $\mathrm{CO}$ and $\mathrm{Pt}$ sites is very strong, active $\mathrm{Pt}$ sites are readily blocked leading to a decrease in catalytic activity.

The strong coupling of light with charge carriers in plasmonic nanostructures has been lately considered ideally suited to accelerate sluggish and complex multi-electron electrochemical reactions. ${ }^{9-13}$ This is due to the generation of energetic charge carriers, hot electrons and holes, through the localized surface plasmon resonance (LSPR) effects occurring in noble metal nanostructures. The integration of LSPR structures onto electrochemical interfaces has thus become an essential part for improving electrocatalytic redox processes ${ }^{13-22}$ In spite of its large potential for boosting catalytic transformations, current advancement of plasmon-enhanced electrocatalysis towards direct methanol oxidation is still under investigation. ${ }^{12,}$ 17-19 In this context, it has been demonstrated that bimetallic AgPt hollow nanoparticles with an ultrathin shell of less than $2 \mathrm{~nm}$ Pt enhanced the electrocatalytic activity towards methanol oxidation in basic media and $\mathrm{CO}$ poisoning tolerance. ${ }^{18}$ Light irradiation at $600 \mathrm{~mW} / \mathrm{cm}^{2}$ resulted in a current density of $18.8 \mathrm{~mA} / \mathrm{cm}^{2} .{ }^{18}$ Huang et al. prepared palladium-silver alloy nanotubes and found that the peak current density increased with increasing the excitation intensity in a linear fashion to reach a current density of $6 \mathrm{~A} / \mathrm{mg} \mathrm{Pt}$ under $530 \mathrm{~nm}$ light illumination at a power of $1.2 \mathrm{~W} / \mathrm{cm}^{2} \cdot{ }^{12}$ Gold nanofiber-based electrodes revealed to be efficient for plasmon-enhanced electrocatalysis of methanol, notably in decreasing the passivation due to $\mathrm{CO}$ adsorption during electrocatalysis?. Highly ordered, porous $\mathrm{ZnO} / \alpha-\mathrm{Fe}_{2} \mathrm{O}_{3} / \mathrm{Au}$ nanotube arrays offered efficient and stable operation for methanol oxidation to formaldehyde with a current density of $1.85 \mathrm{~mA} / \mathrm{cm}^{2} .{ }^{19}$ The catalytic process was 
believed to occur through hot electrons formation in the gold nanostructures, followed by electron injection into $\alpha-\mathrm{Fe}_{2} \mathrm{O}_{3}$, which flow into $\mathrm{ZnO}$. The resultant electron-deficient gold nanostructures oxidize methanol and return to their original metallic state. ${ }^{19}$

Lately Chen et al. synthesized anisotropic Pt-edged $\mathrm{Au}$ nanodisks as catalysts for plasmon-enhanced electrochemical methane oxidation. A 3-fold higher catalytic currents were obtained under visible light irradiation than under dark conditions. ${ }^{23}$ Free-standing nanopourous gold electrodes were proposed by Wang et al. for direct plasmon enhanced electro-oxidation of methanol. ${ }^{24}$ These Schottky-barrier-free plasmonic catalysts enhanced significantly the electro-oxidation of methanol, reaching maximal current densities of 531 $\mu \mathrm{A} / \mathrm{cm}^{2}$.

In this study, we investigated the efficiency of gold nanoperforated electrodes decorated with PtRu nanostructures through electrochemical deposition (AuNHs/PtRu) for methanol oxidation in basic medium under light illumination. Indeed, PtRu bimetallic nanostructures are recognized as one of the best bimetallic catalysts for the electro-oxidation of small organic molecules, ${ }^{21,} 25$ as well for the methanol oxidation reaction ${ }^{3-30}$ They are less sensitive to surface poisoning as they are able to oxidize intermediates, such as $\mathrm{CO}$, at reduced overpotentials. Tian et al. reported in this respect a PtRu nanoparticle supported nanoporous gold electrode for direct methanol oxidation. ${ }^{29}$ Owing to the reduced $\mathrm{CO}$ adsorption energy, this electrode showed a 3-fold enhanced methanol oxidation activity when compared to a commercial PtRu/C anode. The influence of the Pt-shell thickness of $\mathrm{Pt} / \mathrm{Ru}$ core-shell nanostructures on the methanol oxidation reaction (MOR) was investigated lately by Klein et al. They demonstrated that the MOR activity increases with increasing Pt film thickness, whereas the selectivity for $\mathrm{CO}_{2}$ formation remains essentially constant. ${ }^{28}$ Multiwalled carbon nanotubes functionalized by oxygen plasma and decorated with $\mathrm{Pt} / \mathrm{Ru}$ nanoparticles were used by Chetty et al. for electrochemical methanol oxidation. ${ }^{26}$ Electrochemical deposition of $\mathrm{Pt} / \mathrm{Ru}$ nanoparticles onto graphene nanoribbons electrodes resulted in methanol oxidation anodes with substantial activity $(960.2 \mathrm{~mA} / \mathrm{mg})$ and long-time stability.

Perforated gold thin films were chosen in this work as anodes for methanol oxidation due to their strong plasmonic activity under light illumination in the near infrared and good electrochemical stability. ${ }^{13,22,31}$ Indeed, the use of perforated gold thin films was motivated by the demonstrated promotional role of gold ${ }^{2}$ and gold nanostructures on the methanol oxidation in the literature. ${ }^{23,33-35}$ The AuNHs/PtRu interface achieved 1.3 times increase of the recorded current density under laser light illumination at $980 \mathrm{~nm}$ using a power density of $2 \mathrm{~W} / \mathrm{cm} \quad 2$, 
reaching $17.2 \mathrm{~mA} / \mathrm{cm}^{2}$. No increase in the current density was observed on a non-patterned gold thin film when irradiated under the same conditions, underlining the plasmonic effect.

\section{RESULTS AND DISCUSSION}

\section{Gold nanohole arrays modified with PtRu nanostructures (AuNHs/PtRu)}

The electrode used for methanol oxidation (Figure 1a) was formed in a two-step process. First, a gold nanohole array (AuNHs) with holes of an average diameter of $630 \mathrm{~nm}$ and center-to-center spacing of $980 \mathrm{~nm}$ was constructed using colloidal nanolithography as shown in recent articles. ${ }^{13,20}$ The gold thin film was deposited on top of an ultra-thin $(<5 \mathrm{~nm})$ of $\mathrm{Ti} / \mathrm{TiO}_{2}$ adhesion layer, as mechanistic investigations revealed that $\mathrm{Ti} / \mathrm{TiO}{ }_{2} / \mathrm{AuNHs}$ based plasmonic electrodes are an efficient source of hot electrons, contributing to their injection into the underlying $\mathrm{TiO}_{2}$-based adhesion layer and improve the electrochemical reduction of water. ${ }^{13}$ Indeed, such electrodes support LSPR modes (Figure 1b) at $660 \mathrm{~nm}$ with a broad maximum at around $980 \mathrm{~nm}$ with an increase in absorption $<500 \mathrm{~nm}$ due to the underlying Kapton substrate as reported before.

The AuNHs electrodes were further modified with metallic nanostructures via electrodeposition at $-0.8 \mathrm{~V}\left(v s . \mathrm{Ag} / \mathrm{AgCl}\right.$ ) from a solution containing $\mathrm{K} \quad{ }_{2} \mathrm{PtCl}_{6}$ and $\mathrm{RuCl}_{3}$ in different molar ratios (Table 1). A representative cyclic voltammogram of an aqueous solution of $\mathrm{K}_{2} \mathrm{PtCl}_{4} / \mathrm{RuCl}_{3}(1 / 1)$ is seen in Figure 1b. In an anodic scan, $\mathrm{Pt}-\mathrm{O}$ and $\mathrm{Ru}-\mathrm{O}$ formation starts at approximately $0.8 \mathrm{~V}$ (peak I). In the cathodic scan reduction occurs around $0.5 \mathrm{~V}$ (peak II) with a clearly visible hydrogen absorption with redox couples at about $-0.18 /-0.37 \mathrm{~V}$ (peak III / peak IV). The UV/Vis absorption of this interface (Figure 1c) showed a strong overall increase in light absorption, partially masking the plasmon band at $980 \mathrm{~nm}$. 

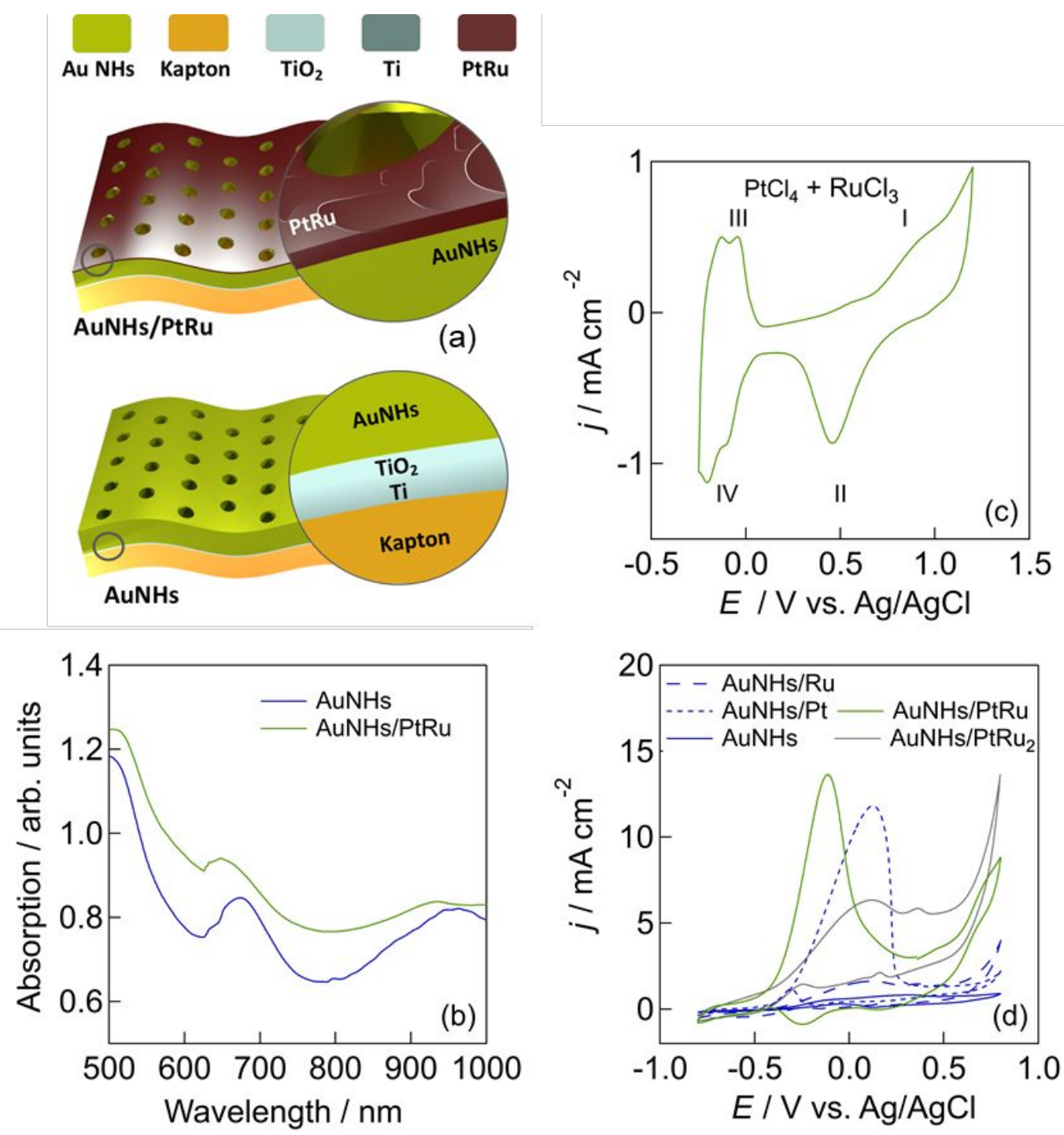

Figure 1. Characteristics of AuNHs/PtRu electrodes. (a) Schematics of plasmon-electrocatalytic electrode used in this work. (b) UV/vis absorption spectra of AuNHs (blue) and AuNHs/PtRu (green). (c) Cyclic voltammogram in an aqueous solution of $\mathrm{NaCl}$ (0.5 M) containing $\mathrm{K}_{2} \mathrm{PtCl}_{4} / \mathrm{RuCl}_{3}(1 / 1)$, scan rate $=20 \mathrm{mV} / \mathrm{s}$. (d) Cyclic voltammograms in 0.1 $\mathrm{M} \mathrm{NaOH} / 0.1 \mathrm{M} \mathrm{CH}_{3} \mathrm{OH}$ for the studied samples (see Table 1).

The influence on the molar ratio of $\mathrm{K}_{2} \mathrm{PtCl}_{4} / \mathrm{RuCl}_{3}$ on the electrocatalytic activity of the different electrodes for methanol oxidation in $\mathrm{NaOH}(0.1 \mathrm{M})$ is seen in Figure 1d. In order to ensure correct comparison among the electrodes, ${ }^{25}$ the electrochemically active surface area (EASA) was determined and used for comparing the current densities involved. The AuNHs modified with $\mathrm{K}_{2} \mathrm{PtCl}_{4} / \mathrm{RuCl}_{3}(1 / 1)$ gave the best methanol oxidation results with a catalytic peak at $-0.12 \mathrm{~V} v s . \mathrm{Ag} / \mathrm{AgCl}$ during the forward scan associated with the electro-oxidation of methanol with a current density of $13.7 \mathrm{~mA} / \mathrm{cm}^{2}$. The AuNHs system shows no electrocatalytic 
activity. Figure 1d furthermore underlines that the AuNHs cathode does not show any activity towards methanol oxidation; the same is true for AuNHs/Ru only. This indicates that the main catalytic activity is via the Pt component of the system.

Table 1. Methanol oxidation characteristics of AuNHs electrodes modified by electrodeposition at $\mathbf{- 0 . 8} \mathrm{V}$ with $\mathrm{Pt}$, $\mathrm{Ru}$, and PtRu deposits from different initial solutions

\begin{tabular}{|c|c|c|c|c|}
\hline Substrate & $\begin{array}{l}\mathrm{K}_{2} \mathrm{PtCl}_{4} \\
(\mathrm{mM})\end{array}$ & $\begin{array}{l}\mathrm{RuCl}_{3} \\
(\mathrm{mM})\end{array}$ & $\underset{\left(\mathrm{mA} / \mathrm{cm}^{2}\right)}{j_{\max }}$ & $\begin{array}{c}E_{\text {peak }} \\
(\mathrm{V} v s . \mathrm{Ag} / \mathrm{AgCl})\end{array}$ \\
\hline $\mathrm{AuNHs} / \mathrm{Ru}$ & 0.0 & 2.0 & 1.5 & 0.11 \\
\hline $\mathrm{AuNHs} / \mathrm{Pt}$ & 2.0 & 0.0 & 11.8 & 0.13 \\
\hline AuNHs/PtRu & 1.0 & 1.0 & 13.7 & -0.12 \\
\hline $\mathrm{AuNHs} / \mathrm{PtRu}_{2}$ & 0.5 & 1.0 & 6.3 & 0.11 \\
\hline
\end{tabular}

Figure 2a displays the scanning electron microscopy (SEM) images of the AuNHs electrode before and after PtRu deposition with a ratio of $1 / 1$. A granulated structured film is evidenced on top of the AuNHs after electrochemical deposition PtRu with a thickness of about $20 \mathrm{~nm}$. The electron dispersive spectroscopy (EDS) mapping of $\mathrm{Au}, \mathrm{Pt}$ and $\mathrm{Ru}$ (Figures 2b-2d) revealed that $\mathrm{Pt}$ and $\mathrm{Ru}$ were preferential present on the top of the AuNHs. 
(a)

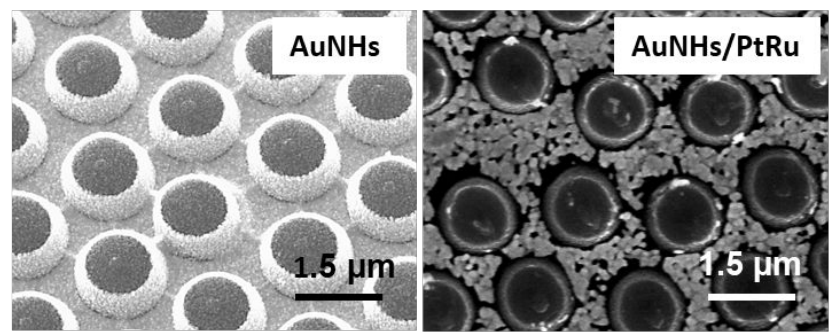

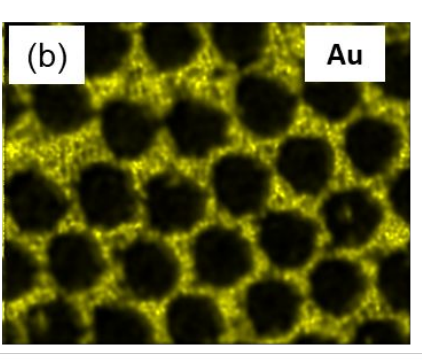

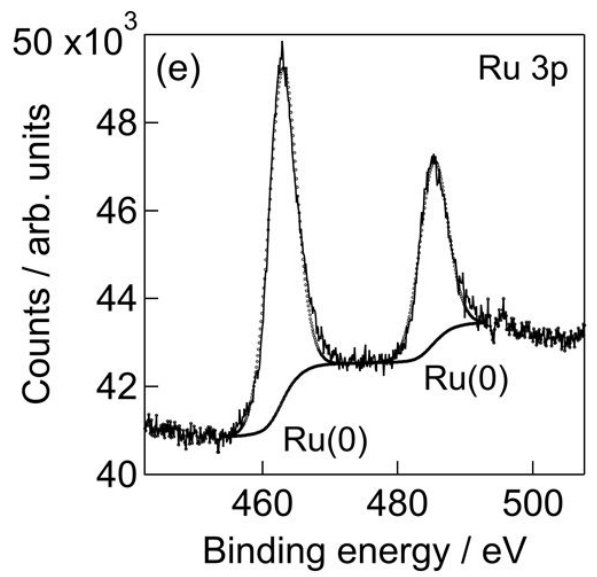

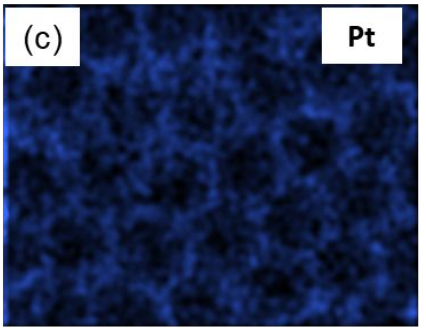
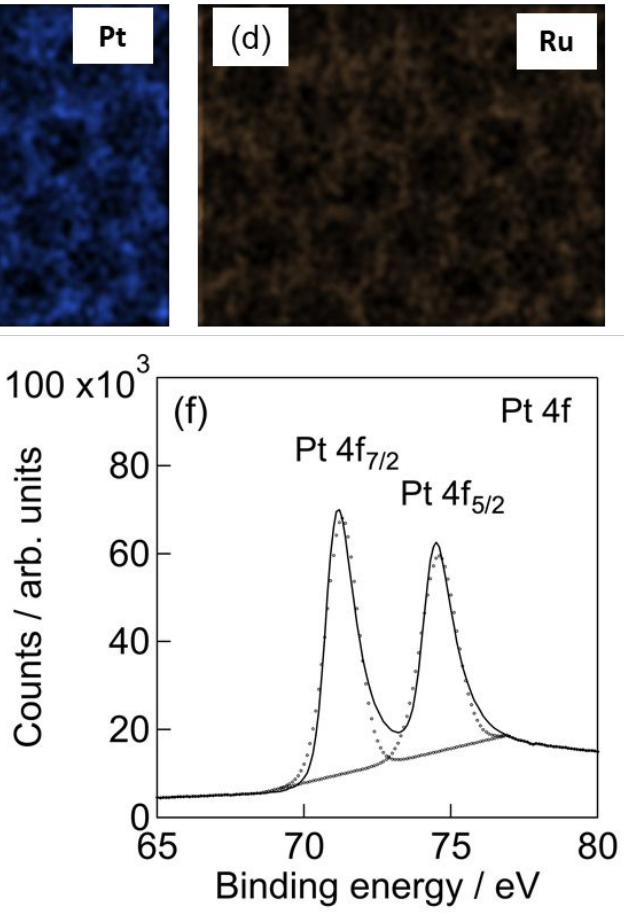

Figure 2. Physico-chemical features of AuNHs/PtRu electrodes. (a) SEM images of AuNHs and AuNHs/PtRu. (b-d) EDS mapping of $\mathrm{Au}$ (b), Pt (c) and Ru (d) of the AuNHs/PtRu electrode. (e) Core level spectra of Ru 3p. (f) Core level spectrum of Pt 4f.

To get more information on the chemical nature of the PtRu particulate thin film, X-ray photoelectron spectroscopy (XPS) analysis was performed. The high-resolution spectrum of the Pt $4 \mathrm{f}$ band (Figure 2f) exhibited bands at 71.1 and $74.5 \mathrm{eV}$ corresponding to $\mathrm{Pt} 4 \mathrm{f} 7 / 2$ and $\mathrm{Pt} 4 \mathrm{f5} / 2$ of metallic Pt, while the core level XPS spectrum of the Ru 3p (Figure 2e) can be curve-fitted with bands at $461.2(\mathrm{Ru} 3 \mathrm{p} 3 / 2)$ and $484.3 \mathrm{eV}(\mathrm{Ru} 3 \mathrm{p} 5 / 2)$ ascribed to metallic Ru. The mass percentage of PtRu present on the AuNHs was determined as 52 mass \% $\mathrm{Pt}$ ) to 48 mass $\% \mathrm{Ru}$ in good agreement with the molar ratio in solution of $1 / 1$.

\section{Methanol oxidation under light irradiation}

Figure 3a depicts the electrocatalytic behaviour of AuNHs/PtRu electrodes in $0.1 \mathrm{M}$ $\mathrm{NaOH} / 0.1 \mathrm{M} \mathrm{CH}_{3} \mathrm{OH}$ under light irradiation at 980 and $808 \mathrm{~nm}$ at $2 \mathrm{~W} / \mathrm{cm}$. The AuNHs/PtRu 
electrode exhibited a catalytic peak at $-0.12 v s . \mathrm{Ag} / \mathrm{AgCl}$ during the forward scan associated with the electro-oxidation of methanol. During the backward scan, a band at $-0.40 \mathrm{~V} v s$. $\mathrm{Ag} / \mathrm{AgCl}$ is observed, attributed to the additional oxidation of absorbed carbonaceous species such as $\mathrm{CO}$ to $\mathrm{CO}_{2} \cdot{ }^{18}$ Under light illumination at $980 \mathrm{~nm}(2 \mathrm{~W} / \mathrm{cm})$, an increase in the oxidation current density to $17.2 \mathrm{~mA} / \mathrm{cm}^{2}$ was recorded, which accounts for an increase of 1.3 times (Figure 3a). This effect was less pronounced upon laser light irradiation at $808 \mathrm{~nm}$, where indeed a minimum is observed in the UV/Vis absorption spectrum (Figure 1b). As expected for a plasmon-mediated effect, the acceleration of electrochemical methanol oxidation is not only wavelength responsive (Figure 3a) but depends in addition on the incident laser power density (Figure 3b). No increase in the current density was recorded on a non-plasmonic gold thin film upon irradiation at 980 or $808 \mathrm{~nm}$ (Figure S2).
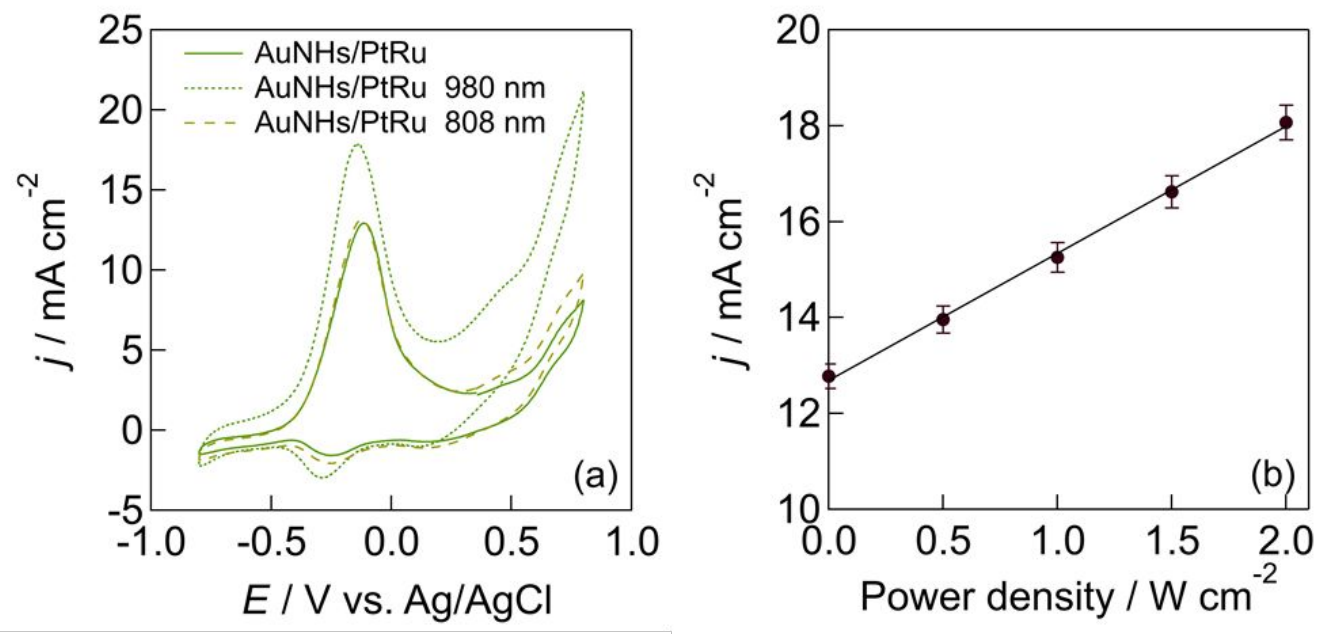

Figure 3. Electrocatalytic methanol oxidation under light irradiation. (a) Cyclic voltammograms of AuNHs/PtRu in $0.1 \mathrm{M} \mathrm{NaOH} / 0.1 \mathrm{M} \mathrm{CH}_{3} \mathrm{OH}$ upon light irradiation at 980 and $808 \mathrm{~nm}$ at $2 \mathrm{~W} / \mathrm{cm}^{2}$. (b) Influence of $980 \mathrm{~nm}$ laser light power density on the current density of AuNHs/PtRu in $0.1 \mathrm{M} \mathrm{NaOH} / 0.1 \mathrm{M} \mathrm{CH}_{3} \mathrm{OH}$.

Table 2 summarizes some of the plasmon-enhanced methanol electrocatalytic systems used to date. 
Table 2. Methanol oxidation systems: Comparison of plasmon-enhanced and other platforms

\begin{tabular}{|c|c|c|c|}
\hline System & Exp. parameters & $\begin{array}{l}\text { Current } \\
\text { densities }\end{array}$ & Ref. \\
\hline MWCNTs/PtRu & $\mathrm{H}_{2} \mathrm{SO}_{4}(0.5 \mathrm{M})$ & $0.2 \mathrm{~A} / \mathrm{mg} \mathrm{Pt}$ & 26 \\
\hline Pt-Ru nanowires & $\mathrm{HClO}_{4}(0.1 \mathrm{M})$ & $0.8 \mathrm{~A} / \mathrm{mg} \mathrm{Pt}$ & 30 \\
\hline \multirow[b]{2}{*}{ PdAg alloy nanotubes } & $\mathrm{NaOH}(0.1 \mathrm{M})$ & & \\
\hline & $\begin{array}{c}530 \mathrm{~nm}, \\
1.2 \mathrm{~W} / \mathrm{cm}^{2}\end{array}$ & $6 \mathrm{~A} / \mathrm{mg} \mathrm{Pt}$ & 12 \\
\hline $\begin{array}{c}\text { Porous graphene } \\
\text { nanoribbons }+\mathrm{Pt} / \mathrm{Ru}\end{array}$ & $\mathrm{H}_{2} \mathrm{SO}_{4}(0.5 \mathrm{M})$ & $0.96 \mathrm{~A} / \mathrm{mg} \mathrm{Pt}$ & 27 \\
\hline $\begin{array}{l}\text { Graphitic carbon nitride } \\
+ \text { AuNPs }\end{array}$ & $\mathrm{KOH}(0.5 \mathrm{M})$ & $0.99 \mathrm{~mA} / \mathrm{cm}^{2}$ & 33 \\
\hline $\begin{array}{l}\text { Free-standing nanoporous } \\
\text { gold film }\end{array}$ & $\begin{array}{l}\mathrm{KOH}(0.5 \mathrm{M}) \\
100 \mathrm{~mW} / \mathrm{cm}^{2}\end{array}$ & $0.35 \mathrm{~mA} / \mathrm{cm}^{2}$ & 24 \\
\hline $\mathrm{Au} / \mathrm{Ag}$ core-shell & $\mathrm{KOH}(0.5 \mathrm{M})$ & $0.38 \mathrm{~mA} / \mathrm{cm}^{2}$ & 34 \\
\hline Nanoporous gold/PtRu & $\mathrm{H}_{2} \mathrm{SO}_{4}(0.5 \mathrm{M})$ & $0.44 \mathrm{~mA} / \mathrm{cm}^{2}$ & 29 \\
\hline $\mathrm{Pt}_{\mathrm{X}-\mathrm{ML}} / \mathrm{Ru}(001)$ & $\mathrm{H}_{2} \mathrm{SO}_{4}(0.5 \mathrm{M})$ & $0.7 \mathrm{mM} / \mathrm{cm}^{2}$ & 28 \\
\hline $\begin{array}{c}\mathrm{ZnO} / \alpha-\mathrm{Fe}_{2} \mathrm{O}_{3} / \mathrm{Au} \text { nanotube } \\
\text { arrays }\end{array}$ & $\begin{array}{c}\mathrm{NaOH}(0.1 \mathrm{M}) \\
\text { Xe lamp irradiation }\end{array}$ & $1.8 \mathrm{~mA} / \mathrm{cm}^{2}$ & 19 \\
\hline $\mathrm{Pt}$ & $\mathrm{NaOH}(0.1 \mathrm{M})$ & $11.8 \mathrm{~mA} / \mathrm{cm}^{2}$ & This work \\
\hline $\mathrm{PtCu}_{3}$ & $\mathrm{HClO}_{4}(0.1 \mathrm{M})$ & $14.1 \mathrm{~mA} / \mathrm{cm}^{2}$ & 8 \\
\hline $\begin{array}{c}\text { Bimetallic AgPt hollow } \\
\text { nanoparticles }\end{array}$ & $\begin{array}{c}\mathrm{NaOH}(0.5 \mathrm{M}) \\
\text { Xe lamp irradiation } \\
\text { at } 600 \mathrm{~mW} / \mathrm{cm}^{2}\end{array}$ & $18.8 \mathrm{~mA} / \mathrm{cm}^{2}$ & 18 \\
\hline $\mathrm{AuNHs} / \mathrm{PtRu}$ & $\begin{array}{c}\mathrm{NaOH}(0.1 \mathrm{M}) \\
980 \mathrm{~nm}, 2 \mathrm{~W} / \mathrm{cm}^{2}\end{array}$ & $17.2 \mathrm{~mA} / \mathrm{cm}^{2}$ & This work \\
\hline
\end{tabular}

MWCNTs: multiwalled carbon nanotubes, ML: monolayer 


\section{Mechanism}

The conversion of methanol is based not only on the excellent catalytic properties of the $\mathrm{Pt} / \mathrm{Ru}$ nanostructures (mechanism iii in Figure 4a) for methanol, but also on the plasmonic properties of the underlying AuNHs interface. The expected working mechanism for methanol oxidation over AuNHs/PtRu electrodes under light irradiation is shown in Figure 4a. Under laser excitation, localized surface plasmons are generated on the nanopatterned gold film electrode forming electron-hole pairs. To differentiate between temperature effects and the generation of hot carriers, the methanol oxidation reaction was performed at different solution temperatures up to $70{ }^{\circ} \mathrm{C}$. Laser irradiation of AuNHs/PtRu results in an increase of the temperature to about $68{ }^{\circ} \mathrm{C}(980 \mathrm{~nm})$ and $64{ }^{\circ} \mathrm{C}(808 \mathrm{~nm})$ (Figure 4b). Performing methanol oxidation at $70^{\circ} \mathrm{C}$ solution temperature on AuNHs/PtRu showed only a slight enhancement in methanol electro-oxidation (Figure 4c). The thermal effect is clearly weaker than the plasmonic effect observed before at $980 \mathrm{~nm}$ light irradiation and the generated hot carriers as highlighted in Figure 4a is most likely occurring. The generated hot electrons can be further injected into the conduction band of the $\mathrm{Ti} / \mathrm{TiO}_{2}$ underlying adhesion layer (mechanism ii in Figure 4a) and will stabilize the formed generated hot holes $\left(\mathrm{h}^{+}\right)$for methanol oxidation by minimizing the recombination of hot carriers (mechanism i) in the AuNHs/PtRu layer being thus lost for electrocatalysis. Fast generation and injection of charge carriers upon light irradiation are evidenced by the abrupt increase in the current density profile when the $\mathrm{AuNHs} / \mathrm{PtRu}$ interface is biased at $-0.10 \mathrm{~V}$ vs. $\mathrm{Ag} / \mathrm{AgCl}$ and illuminated at $980 \mathrm{~nm}$. A steady state current is obtained after about $1 \mathrm{~min}$, with a decay time of the same time order (Figure 4d). This behavior is different from that observed when illuminated at $808 \mathrm{~nm}$, where no significant current enhancement is observed under irradiation (Figure 4d). 
(a)
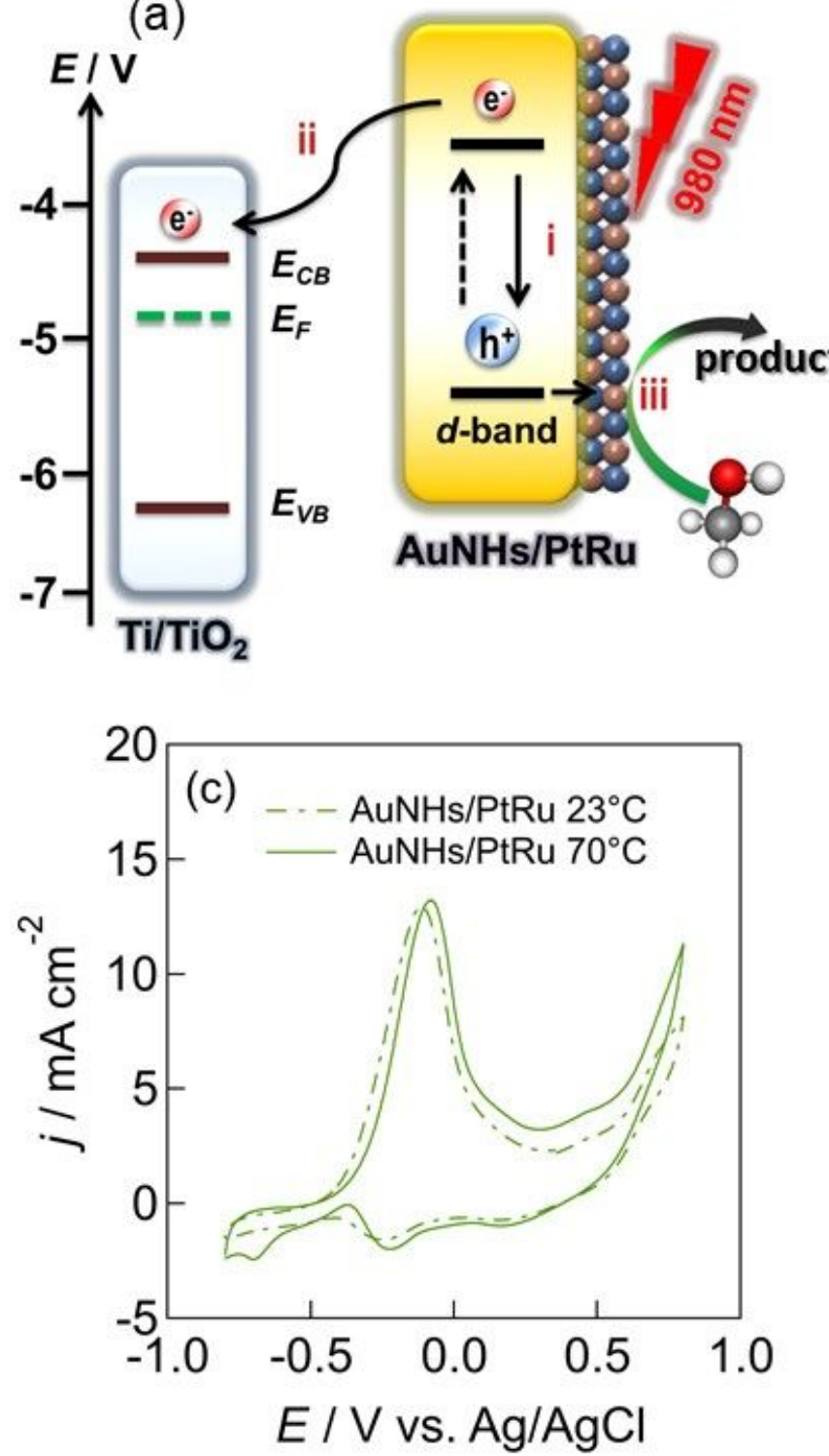
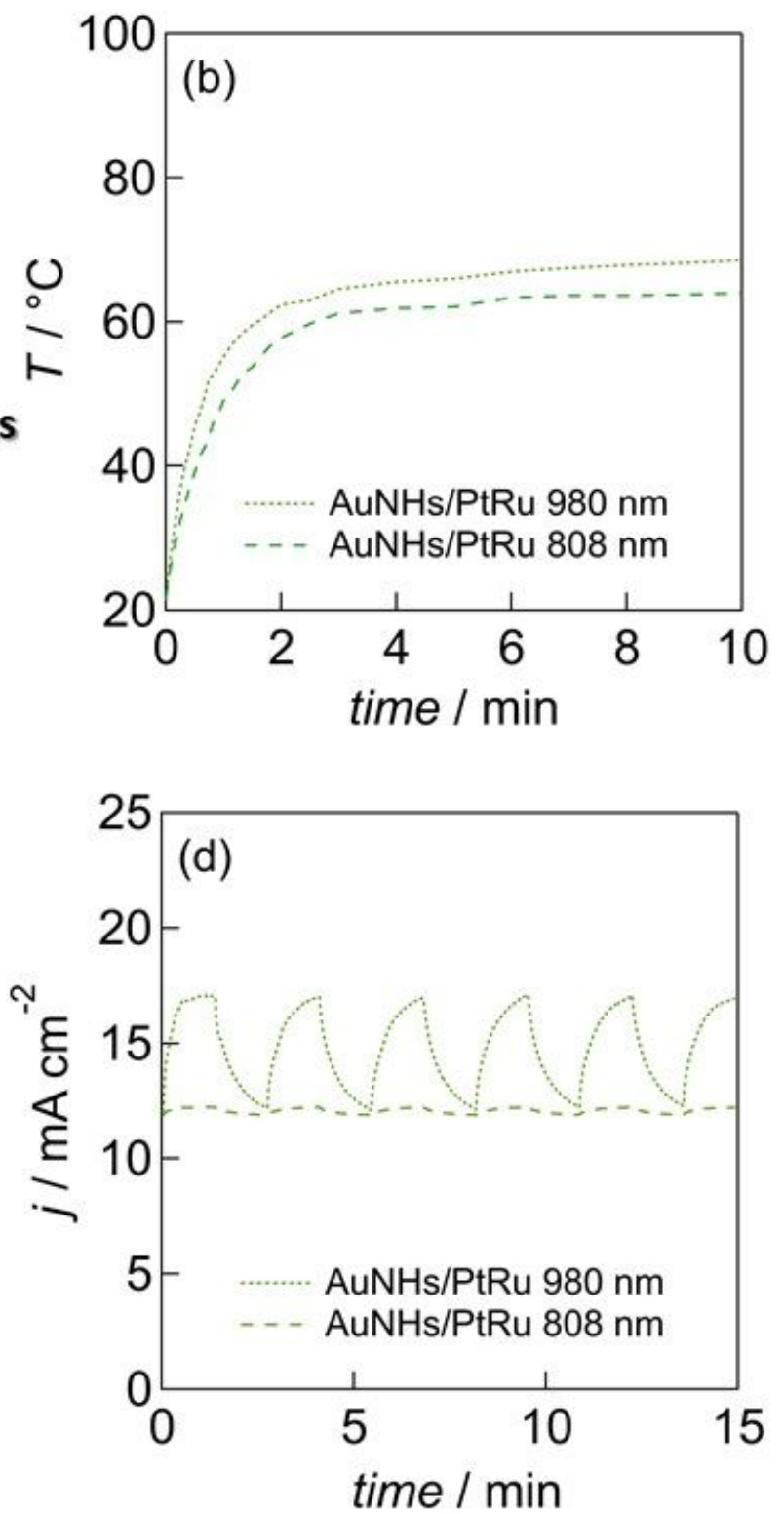

Figure 4. Mechanistic considerations for methanol oxidation. (a) Schematic presentation of the mechanism involved in methanol oxidation under plasmonic excitation. (i) recombination of formed charges, (ii) generated hot electrons are injected into the conduction band of the $\mathrm{Ti} / \mathrm{TiO}_{2}$ underlying adhesion layer, (iii) electrochemical conversion on $\mathrm{Pt} / \mathrm{Ru}$ nanostructures. (b) Change of solution temperature upon illumination of AuNHs/PtRu at 980 and $808 \mathrm{~nm}$ at 2 W/cm² for 10 min. (c) Cyclic voltammogram of AuNHs/PtRu in $0.1 \mathrm{M} \mathrm{NaOH} / 0.1 \mathrm{M} \mathrm{CH}_{3} \mathrm{OH}$ at room temperature and at $70{ }^{\circ} \mathrm{C}$ solution temperature. (d) Current density - time curves of biased AuNHs/PtRu under illumination at 980 and $808 \mathrm{~nm}$ at $2 \mathrm{~W} / \mathrm{cm}^{2}$.

In order to gain more insight onto the reaction products, methanol oxidation was carried out at $-0.1 \mathrm{~V}$ vs. $\mathrm{Ag} / \mathrm{AgCl}$ for $2 \mathrm{~h}$ and the solution analyzed by HPLC. $13 \mathrm{mM}$ of methanol were 
converted using this condition. Neither the formation of formaldehyde (HCHO) nor methyl formate could be validated by HPLC analysis. Formic acid ( $\mathrm{HCCOH})$ could be detected with a concentration of $857 \mu \mathrm{M}$, the rest $(12.15 \mathrm{mM})$ is most likely to of gases such as $\mathrm{CO}$ and $\mathrm{CO}_{2}$ mostly.

\section{Stability and Reproducibility}

Cyclic voltammograms for 4 different electrodes are depicted in Figure 5a showing that the interfaces can be reproduced with high accuracy. The long-term stability of AuNHs/PtRu was assessed by recording the change of the current density over cycling time (Figure 5b). After 20.000 cycles, the methanol oxidation current, determined via cyclic voltammetry, decreased by $\sim 20 \%$. This is most likely linked to the loss of some of the catalyst over time and/or surface oxidation (Figure 5c). However, as seen from the SEM image in Figure 5d, the interface morphology was not altered even after 20.000 cycles.
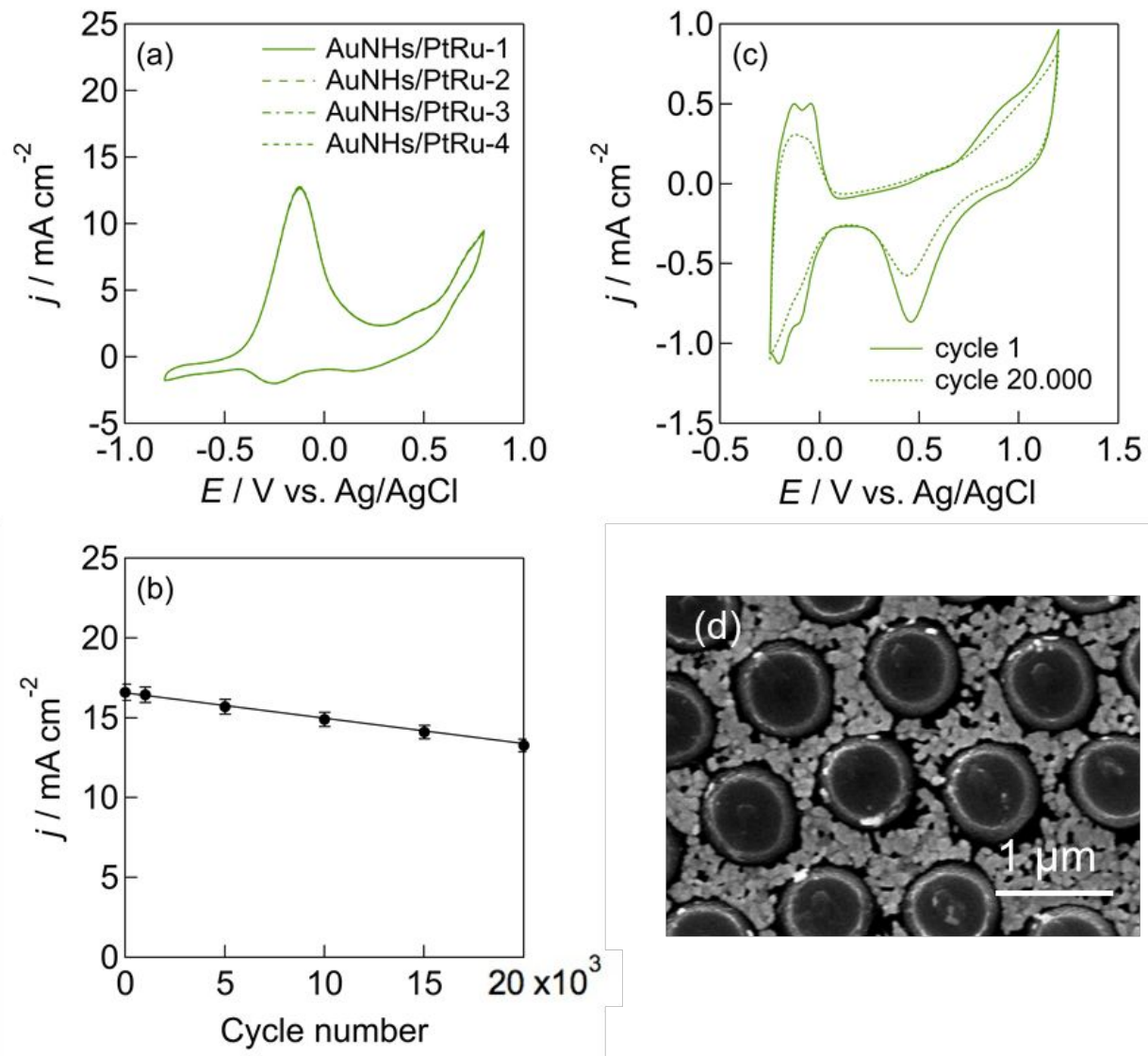

Figure 5. Interface characteristics. (a) $\mathrm{CV}$ curves of $4 \mathrm{AuNHs} / \mathrm{PtRu}$ interfaces in $0.1 \mathrm{M}$ $\mathrm{NaOH} / 0.1 \mathrm{M} \mathrm{CH}_{3} \mathrm{OH}$ at a scan rate of $20 \mathrm{mV} / \mathrm{s}$ in dark. (b) Variation of methanol oxidation current under $980 \mathrm{~nm}\left(2 \mathrm{~W} / \mathrm{cm}^{2}\right)$ light illumination over 20.000 cycles. (c) Cyclic 


\section{Acknowledgements}

Financial supports from the Centre National de la Recherche Scientifique (CNRS), the University of Lille and the Hauts-de-France region, are acknowledged. P.L. thanks Chinese government for the China Scholarship Council Award. S.M. is a Research Associate of the Belgian F.R.S. - FNRS and acknowledges financial support via the SELFPHON project. The authors thank the REALCAT platform funded by a French governmental subsidy managed by 
the French National Research Agency (ANR) within the frame of the "Future Investments' program (ANR-11-EQPX-0037)”. The Hauts-de- France region, FEDER, Ecole Centrale de Lille, and Centrale Initiatives Foundation are also warmly acknowledged for their financial contributions to the acquisition of REALCAT platform equipment

\section{EXPERIMENTAL SECTION}

\section{Materials}

Ruthenium (III) chloride $\left(\mathrm{RuCl}_{3}, \mathrm{Ru}\right.$ content $\left.45-55 \%\right)$, potassium tetrachloroplatinate(II) $\left(\mathrm{K}_{2} \mathrm{PtCl}_{4}, \geq 99.9 \%\right.$ trace metals basis), Sodium chloride $(\mathrm{NaCl}, \geq 99.5 \%)$, methanol ( $\mathrm{MeOH}$, $\geq 99.9 \%$ ), sodium hydroxide $(\mathrm{NaOH}, \geq 98 \%)$, hydrochloric acid $(\mathrm{HCl}, 38 \%)$, sulfuric acid $(\geq 99.9 \%$ ), formic acid ( $\geq 98 \%)$ were purchased from Sigma-Aldrich, France and used without further purification.

Kapton $\mathrm{HN}$ polyimide foils $\left(10 \times 10 \mathrm{~mm}^{2}\right.$, thickness $\left.5 \mu \mathrm{m}\right)$ were obtained from Goodfellow, Cambridge, UK and polystyrene beads (1000 nm) from Microparticles GmbH, Germany.

Thin film electrodes were formed by physical vapour deposition of $5 \mathrm{~nm}$ Ti onto Kapton followed by $50 \mathrm{~nm}$ gold as reported before.

\section{Fabrication of gold nanohole arrays (AuNHs)}

Kapton was modified with gold nanoholes, according to our previous works. ${ }^{13,22}$ In short, a monolayer of $1000 \mathrm{~nm}$ polystyrene beads was deposited onto Kapton by self-assembly, followed by $\mathrm{SF}_{6}$ and oxygen plasma etching for $8 \mathrm{~min}$ (gas flow of $2 \mathrm{sccm}$ and $30 \mathrm{sccm}$, respectively, at $10 \mathrm{mTorr}$ chamber pressure) to reduce the particle size. The samples were then coated with $5 \mathrm{~nm}$ Ti and $50 \mathrm{~nm}$ Au at a constant deposition rate of $0.2 \AA / \mathrm{s}$ using physical vapor deposition. The beads were removed by peeling the surface with Blue Low Tack tape (Semiconductor Equipment Corp.). The surfaces were copiously washed with acetone and dried under nitrogen flow. The arrays display holes of $630 \mathrm{~nm}$ average diameter and center-to-center spacing of $980 \mathrm{~nm}$. 
Preparation of Au nanohole arrays coated with PtRu nanoparticles (AuNHs/PtRu)

$\mathrm{PtRu}$ nanostructures were deposited onto AuNHs electrodes via electrodeposition from a solution of $\mathrm{NaCl}, \mathrm{RuCl}_{3}$, and $\mathrm{K}_{2} \mathrm{PtCl}_{4}$ at $\mathrm{pH} 4$ under $\mathrm{N}_{2}$ atmosphere. Different molar ratio of $\mathrm{Pt}$ / $\mathrm{Ru}$ in an aqueous solution of $\mathrm{NaCl}(0.5 \mathrm{M})$ were investigated: $\mathrm{RuCl} \quad{ }_{3}(2 \mathrm{mM}), \mathrm{K}_{2} \mathrm{PtCl}_{4}(2$ $\mathrm{mM}), \mathrm{K}_{2} \mathrm{PtCl}_{4}(1 \mathrm{mM}) / \mathrm{RuCl}_{3}(1 \mathrm{mM}), \mathrm{K}_{2} \mathrm{PtCl}_{4}(0.5 \mathrm{mM}) / \mathrm{RuCl}_{3}(1.0 \mathrm{mM})$.

Before the electrochemical deposition process, the potential was kept at $+0.2 \mathrm{~V} v s$. $\mathrm{Ag} / \mathrm{AgCl}$ for $2.5 \mathrm{~s}$ to activate the substrate surface. Deposition was carried out at $-0.8 \mathrm{~V} v s$. $\mathrm{Ag} / \mathrm{AgCl}$ for $2.5 \mathrm{~s}$ followed by a potential pulse of $0.2 \mathrm{~V}(v s . \mathrm{Ag} / \mathrm{AgCl})$ for $3 \mathrm{~s}$. This was repeated 2 times.

\section{Characterization}

Scanning electron microscopy images were obtained using an electron microscope ULTRA 55 (Zeiss) equipped with a thermal field emission emitter with $10 \mathrm{kV}$ accelerating voltage, four different detectors (EsB detector with filter grid, high efficiency in-lens Secondary Electron detector, Everhart-Thornley Secondary Electron detector and Bruker XFlash 4010 Silicon Drift Detector for EDS imaging).

X-ray photoelectron spectroscopy (XPS) experiments were carried out using an AXIS Ultra DLD spectrometer from Kratos analytical, equipped with a monochromatic $\mathrm{Al} \mathrm{K} \alpha$ radiation $(1486.6 \mathrm{eV})$ operating at $225 \mathrm{~W}(15 \mathrm{~mA}, 15 \mathrm{kV})$.

The UV/Vis absorption spectra were recorded using a Perkin Elmer Lambda UV/Vis 950 spectrophotometer in a quartz cuvette $(1 \mathrm{~cm})$. The wavelength range was $200-1100 \mathrm{~nm}$.

\section{HPLC analysis of the solutions}

Chemicals in solution before and after reaction were analysed on an HPLC equipped with a UV detector SPD-20A and a refractive index detector RID-20A (Shimadzu, Japan), using a Bio-Rad Aminex HPX-87H (300 x $7.8 \mathrm{~mm}$ ) cartridge column. Injection volumes of $10 \mu \mathrm{L}$ were used for all the samples. The water elution phase contained $5 \mathrm{mM}$ sulfuric acid. Elution was carried out in isocratic mode, at $0.6 \mathrm{~mL} \cdot \mathrm{min}^{-1}$, with a $40{ }^{\circ} \mathrm{C}$ oven temperature for the column, and a total run time of $25 \mathrm{~min}$. The products were detected at $210 \mathrm{~nm}$ in UV mode and in refractive index (RI) mode. The reaction products were detected at the following retention times and modes: formic acid: $13.1 \mathrm{~min} / 210 \mathrm{~nm} \& \mathrm{RI}$, formaldehyde: $13.8 \mathrm{~min} / \mathrm{RI}$, methanol: $19.5 \mathrm{~min} / \mathrm{RI}$. A calibration curve was realised for acetic acid and methanol quantification, with concentration range of 0.5 to $10 \mathrm{mM}$ and 0.5 to $500 \mathrm{mM}$ respectively, over 10 points. 


\section{Electrochemical experiments}

Electrochemical measurements were acquired using a potentiostat/galvanostat (Metrohm Autolab) electrochemical test station in a standard 3-electrode system with AuNHs and $\mathrm{AuNHs} / \mathrm{PtRu}$ as the working electrode, a carbon plate as the counter electrode and an $\mathrm{Ag} / \mathrm{AgCl}$ (3.5 $\mathrm{M} \mathrm{KCl)}$ as the reference electrode.

Cyclic voltammetry (CV) measurements were performed in $\mathrm{NaOH}(0.1 \mathrm{M}) / \mathrm{CH}{ }_{3} \mathrm{OH}(0.1 \mathrm{M})$ solution at a scan rate of $20 \mathrm{mV} / \mathrm{s}$.

The electrochemically active surface area (EASA) was derived from the double layer capacitance method $\left(\mathrm{C}_{\mathrm{dl}}\right)$ (see SI, Figure S1) and was determined as: $\mathrm{Au}(1 \mathrm{~cm})$ ), AuNHs (0.92 $\left.\mathrm{cm}^{2}\right)$, AuNHs/PtRu $\left(3 \mathrm{~cm}^{2}\right), \mathrm{Au} / \mathrm{PtRu}\left(1.66 \mathrm{~cm}^{2}\right)$.

For plasmon-enhanced electrocatalysis, the electrodes were illuminated with light from a continuous wave laser (808 and $980 \mathrm{~nm}$, Gbox model, Fournier Medical Solutions) with a laser power output between 0.5 and $2 \mathrm{~W} / \mathrm{cm}^{2}$. All measurements were repeated at least four times. The amount of $\mathrm{CO}_{2}$ formed $\left(\mathrm{m}\right.$ in $\mathrm{mol} / \mathrm{cm}^{2}$ ) was calculated according to $\mathrm{m}=\mathrm{n} * \mathrm{~F} / \mathrm{Q}$, with $\mathrm{F}$ the Faraday constant $(96485 \mathrm{C} / \mathrm{mol}), \mathrm{Q}\left(\mathrm{C} / \mathrm{cm}^{2}\right)$ the charge passed during the experiment and $\mathrm{n}=$ 6 the number of electrons transferred.

\section{ASSOCIATED CONTENT}

\section{Supporting Information}

The Supporting Information (SI) is available free of charge

Figure S1: determination of active surface area, Figure S2: electrocatalytic results on gold thin films and Pt electrodes.

\section{Notes}

The authors declare no competing financial interest.

\section{REFERENCES}

1. Liu, H.; Song, C.; Zhang, L.; Zhang, J.; Wang, H.; Wilkinson, D. P., A Review of Anode Catalysis in the Direct Methanol Fuel Cell. J. Power Sources 2006, 155, 95-110.

2. Kamarudin, S. K.; Achmad, F.; Daud, W. R. W., Overview on the Application of Direct Methanol Fuel Cell (DMFC) for Portable Electronic Devices. Int. J. Hydrogen Energy 2009, 34, 6902-6916. 
3. Chung, D. Y.; Lee, K.-J.; Sung, Y.-E., Methanol Electro-Oxidation on the Pt Surface: Revisiting the Cyclic Voltammetry Interpretation. J. Phys. Chem. C, 2016, 120, 9028-9035. 4. Tian, X. L.; Wang, L.; Deng, P.; Chen, Y.; Xia, B. Y., Research Advances in Unsupported Pt-Based Catalysts for Electrochemical Methanol Oxidation. J. Energy Chem. 2017, 26, 1067-1076.

5. Alia, S. M.; Zhang, G.; Kisailus, D.; Li, D.; Gu, S.; Jensen, K.; Yan, Y., Porous Platinum Nanotubes for Oxygen Reduction and Methanol Oxidation Reactions. Adv. Funct. Mater. 2010, 20, 3742-3746.

6. Huang, W.; Wang, H.; Zhou, J.; Wang, J.; Duchesne, P. N.; Muir, D.; Zhang, P.; Han, N.; Zhao, F.; Zeng, M.; Zhong, J.; Jin, C.; Li, Y.; Lee, S.-T.; Dai, H., Highly Active and Durable Methanol Oxidation Electrocatalyst Based on the Synergy of Platinum-Nickel Hydroxide-Graphene. Nat. Commun. 2015, 6, 10035.

7. Mansor, M.; Timmiati, S. N.; Lim, K. L.; Wong, W. Y.; Kamarudin, S. K.; Nazirah Kamarudin, N. H., Recent Progress of Anode Catalysts and Their Support Materials for Methanol Electro-oxidation Reaction. Int. J. Hydrogen Energy 2019, 44, 14744-14769.

8. Xia, B. Y.; Wu, H. B.; Wang, X.; Lou, X. W., One-Pot Synthesis of Cubic PłCu Nanocages with Enhanced Electrocatalytic Activity for the Methanol Oxidation Reaction. $J$. Am. Chem. Soc. 2012, 134, 13934-13937.

9. Choi, C. H.; Chung, K.; Nguyen, T.-T. H.; Kim, D. H., Plasmon-Mediated Electrocatalysis for Sustainable Energy: From Electrochemical Conversion of Different Feedstocks to Fuel Cell Reactions. ACS Energy Lett. 2018, 3, 1415-1433.

10. Wang, C.; Nie, X.-G.; Shi, Y.; Zhou, Y.; Xu, J.-J.; Xia, X.-H.; Chen, H.-Y., Direct Plasmon-Accelerated Electrochemical Reaction on Gold Nanoparticles. ACS Nano 2017, 11, $5897-5905$.

11. Xu, J.; Gu, P.; Birch, D. J. S.; Chen, Y., Plasmon-Promoted Electrochemical Oxygen Evolution Catalysis from Gold Decorated $\mathrm{MnO}_{2}$ Nanosheets under Green Light. Adv. Funct. Mater. 2018, 28, 1801573.

12. Huang, L.; Zou, J.; Ye, J.-Y.; Zhou, Z.-Y.; Lin, Z.; Kang, X.; Jain, P. K.; Chen, S., Synergy between Plasmonic and Electrocatalytic Activation of Methanol Oxidation on Palladium-Silver Alloy Nanotubes. Angew. Chem. Int. Ed. 2019, 58, 8794-8798.

13. Pang, L.; Barras, A.; Mishyn, V.; Sandu, G.; Melinte, S.; Subramanian, P.; Boukherroub, R.; Szunerits, S., Enhanced Electrocatalytic Hydrogen Evolution on a Plasmonic Electrode: The Importance of the $\mathrm{Ti} / \mathrm{TiO}_{2}$ Adhesion Layer. J. Mater. Chem. A 2020, 8, 13980-13986. 
14. Shi, F.; He, J.; Zhang, B.; Peng, J.; Ma, Y.; Chen, W.; Li, F.; Qin, Y.; Liu, Y.; Shang, W.; Tao, P.; Song, C.; Deng, T.; Qian, X.; Ye, J.; Wu, J., Plasmonic-Enhanced Oxygen Reduction Reaction of Silver/Graphene Electrocatalysts. Nano Lett. 2019, 19, 1371-1378.

15. Shi, Y.; Wang, J.; Wang, C.; Zhai, T.-T.; Bao, W.-J.; Xu, J.-J.; Xia, X.-H.; Chen, H.-Y., Hot Electron of Au Nanorods Activates the Electrocatalysis of Hydrogen Evolution on MoS 2 Nanosheets. J. Am. Chem. Soc. 2015, 137, 7365-7370.

16. Wang, C.; Zhao, X.-P.; Xu, Q.-Y.; Nie, X.-G.; Younis, M. R.; Liu, W.-Y.; Xia, X.-H., Importance of Hot Spots in Gold Nanostructures on Direct Plasmon-Enhanced Electrochemistry. ACS App. Nano Mater. 2018, 1, 5805-5811.

17. Chen, D.; Zhang, R.; Wang, R.; Dal Negro, L.; Minteer, S. D., Gold Nanofiber-Based Electrodes for Plasmon-Enhanced Electrocatalysis. J. Electrochem. Soc. 2016, 163, H1132-H1135.

18. Bi, J.; Cai, H.; Wang, B.; Kong, C.; Yang, S., Localized Surface Plasmon Enhanced Electrocatalytic Methanol Oxidation of AgPt Bimetallic Nanoparticles with an Ultra-Thin Shell. Chem. Commun. 2019, 55, 3943-3946.

19. Zheng, B.-F.; Ouyang, T.; Wang, Z.; Long, J.; Chen, Y.; Liu, Z.-Q., Enhanced Plasmon-Driven Photoelectrocatalytic Methanol Oxidation on $\mathrm{Au}$ Decorated $\alpha-\mathrm{Fe}_{2} \mathrm{O}_{3}$ Nanotube Arrays. Chem. Commun. 2018, 54, 9583-9586.

20. Nait Saada, T.; Marques da Silva, A. G.; Subramanian, P.; Pang, L.; Adnane, N.; Djafari-Rouhani, B.; Mishyn, V.; Meziane, D.; Melinte, S.; Sandu, G.; Dumeignil, F.; Paul, S.; Wojcieszak, R.; Boukherroub, R.; Szunerits, S., Plasmon-Enhanced Electrocatalytic Oxygen Reduction in Alkaline Media on Gold Nanohole Electrodes. J. Mater. Chem. A 2020, 8, 10395-10401.

21. El-Aziz, A. M.; Hoyer, R.; Kibler, L. A., Preparation and Electrochemical Behavior of PtRu(111) Alloy Single-Crystal Surfaces. ChemPhysChem 2010, 11, 2906-2911.

22. Li, C.; Ye, R.; Bouckaert, J.; Zurutuza, A.; Drider, D.; Dumych, T.; Paryzhak, S.; Vovk, V.; Bilyy, R. O.; Melinte, S.; Li, M.; Boukherroub, R.; Szunerits, S., Flexible Nanoholey Patches for Antibiotic-Free Treatments of Skin Infections. ACS Appl. Mater. Interfaces 2017, 9, 36665-36674.

23. Chen, G.; Sun, M.; Li, J.; Zhu, M.; Lou, Z.; Li, B., Plasmonic Hot Electron Transfer in Anisotropic Pt-Au Nanodisks Boosts Electrochemical Reactions in the Visible-NIR Region. Nanoscale 2019, 11, 18874-18880. 
24. Wang, Z.; Du, J.; Zhang, Y.; Han, J.; Huang, S.; Hirata, A.; Chen, M., Free-Standing Nanoporous Gold for Direct Plasmon Enhanced Electro-Oxidation of Alcohol Molecules. Nano Energy 2019, 56, 286-293.

25. Anantharaj, S.; Kundu, S., Do The Evaluation Parameters Reflect Intrinsic Activity of Electrocatalysts in Electrochemical Water Splitting? ACS Energy Lett. 2019, 4, 1260-1264.

26. Chetty, R.; Maniam, K. K.; Schuhmann, W.; Muhler, M., Oxygen-Plasma-Functionalized Carbon Nanotubes as Supports for Platinum-Ruthenium Catalysts Applied in Electrochemical Methanol Oxidation. ChemPlusChem 2015, 80, 130-135. 27. Torabi, M.; Karimi Shervedani, R.; Amini, A., High Performance Porous Graphene Nanoribbons Electrodes Synthesized via Hydrogen Plasma and Modified by Pt-Ru Nanoclusters for Charge Storage and Methanol Oxidation. Electrochim. Acta 2018, 290, 616-625.

28. Klein, J.; Argast, F.; Engstfeld, A. K.; Brimaud, S.; Behm, R. J., Electro-Oxidation of Methanol on Ru-Core Pt-Shell Type Model Electrodes. Electrochim. Acta 2019, 311, 244-254. 29. Tian, M.; Shi, S.; Shen, Y.; Yin, H., PtRu Alloy Nanoparticles Supported on Nanoporous Gold as an Efficient Anode Catalyst for Direct Methanol Fuel Cell. Electrochim. Acta 2019, 293, 390-398.

30. Huang, L.; Zhang, X.; Wang, Q.; Han, Y.; Fang, Y.; Dong, S., Shape-Control of Pt-Ru Nanocrystals: Tuning Surface Structure for Enhanced Electrocatalytic Methanol Oxidation. $J$. Am. Chem. Soc. 2018, 140, 1142-1147.

31. Szunerits, S.; Boukherroub, R., Preparation and Characterization of Thin Films of SiO on Gold Substrates for Surface Plasmon Resonance Studies. Langmuir 2006, 22, 1660-1663.

32. Assiongbon, K. A.; Roy, D., Electro-Oxidation of Methanol on Gold in Alkaline Media: Adsorption Characteristics of Reaction Intermediates Studied Using Time Resolved Electro-Chemical Impedance and Surface Plasmon Resonance Techniques. Surf. Sci. 2005, 594, 99-119.

33. Siwal, S.; Devi, N.; Perla, V. K.; Ghosh, S. K.; Mallick, K., Promotional Role of Gold in Electrochemical Methanol Oxidation. Catal. Struct. React. 2019, 5, 1-9.

34. Njoki, P. N.; Roots, M. E. D.; Maye, M. M., The Surface Composition of Au/Ag Core/Alloy Nanoparticles Influences the Methanol Oxidation Reaction. ACS App. Nano Mater. 2018, $1,5640-5645$.

35. Kim, J.; Lee, S. W.; Hammond, P. T.; Shao-Horn, Y., Electrostatic Layer-by-Layer Assembled $\mathrm{Au}$ Nanoparticle/MWNT Thin Films: Microstructure, Optical Property, and Electrocatalytic Activity for Methanol Oxidation. Chem. Mater. 2009, 21, 2993-3001. 